\title{
Deciding to act: Teachers' willingness to implement inclusive practices
}

Erika M. Pace ${ }^{1}$, Paola Aiello

\begin{abstract}
This article presents an ongoing study being conducted at the University of Salerno (Italy) to examine the variables, often intertwined, that influence teachers' willingness to shift from fossilised methods of instruction to inclusive teaching strategies. Despite the strong tradition of inclusive education, the long history in pedagogical studies and the investment in teacher training, research has shown that in Italy an integrative model still persists.

Meanwhile, a plethora of research stemming from psychological, sociological and neuroscientific studies, has been conducted on an international level on what affects people's intentions to change behaviour. Among the theoretical constructs and models that have been developed, the Social Cognitive Theory (Bandura, 1986) and the Theory of Planned Behaviour (TPB) (Ajzen, 1988) have been used as conceptual frameworks to guide research on the variables affecting teachers' intentions to act and implement new approaches in order to ensure quality education for all.

The paper provides an overview of the literature available on the studies conducted to identify the theories framing research in this field, the methods and tools most commonly utilized, and the variables affecting the adoption of inclusive practices. The article concludes by outlining the implications for research and teacher education curricula reform.
\end{abstract}

Keywords: Literature review, Social Cognitive Theory, Teacher agency, Theory of Planned Behaviour, Scale development

\section{Introduction}

Worldwide developments in educational policy in recent years have placed great emphasis on inclusive education as the way forward to guarantee that all children, regardless of their ability, gender, language, ethnic or cultural origin, succeed in school (Armstrong, Armstrong \& Spandagou, 2010). Over and above such a challenging endeavour, $21^{\text {st }}$ Century teachers are faced with heterogeneous classes whose students' personal needs and expectations have

${ }^{1} \mathrm{PhD}$ student, University of Salerno (Italy), is the author of the paper.

${ }^{2}$ University of Salerno (Italy), is the co-author of the paper and scientific coordinator of the research. 
drastically evolved due to the rapid changes on a social, economic and cultural level, and the pervasive influence of technology. Therefore, classes have become intricate and complex scenarios which teachers need to unravel in order to find and apply the best possible strategies for the preparation of future generations for the world of work (Commission of the European Communities [CEC], 2007; OECD, 2005; OECD, 2015; Sibilio, 2014).

Since the 90 s a number of initiatives on an international level ${ }^{3}$ have triggered policy and curricula reform with the aim of abolishing dual track systems, as far as possible, and promoting an inclusive teaching-learning approach. In this period the Italian educational system was considered a model for other nations worldwide, since at that time nearly all pupils with a disability were already integrated into mainstream schools and the vast majority of special schools had already been abolished. Yet whereas on policy level Italy, as many other countries, has laid the foundations for the implementation of a fully-inclusive model, on a practical level issues regarding its meaning and implementation remain (Aiello, Corona \& Sibilio, 2014; Armstrong et al., 2010; D'Alessio, Medeghini, Vadalà \& Bocci, 2015; de Anna, 2014; Di Blas \& Ferrari, 2014; European Agency for Development in Special Needs Education [EADSNE], 2010; Hodkinson, 2011; Norwich, 2013; Sibilio, Aiello \& Corona, 2013).

Taking into consideration the demanding school environments teachers are asked to work in, an inclusive educational policy needs to go beyond the integration and education of students with disability and special educational needs in mainstream schools (Chiappetta-Cajola \& Ciraci, 2013). Inclusion has to be considered as an ongoing process (Booth, 2011) at the "heart of education and social policy" (Mittler, 2000, p. 2) where difference is considered a resource and an opportunity (Sliwka, 2010). Such a perspective requires radical changes in pedagogy, curricula, classroom practice (Rossi \& Giaconi, 2016), assessment, group organisation within schools and classrooms (Booth, 2011; Mittler, 2000), as well as a radical shift in attitudes and a willingness on the part of schools - especially teachers - to implement such transformations.

Teachers, in fact, have been identified as the main catalysts without whose approval no policy, philosophy or strategy can be translated into action for this revolutionary undertaking. As postulated by Kuyini and Desai (n.d.) "[i]ndeed, without a human vehicle, the structural, organisational and resource provisions are of little or no use". Evidence of this are the plethora of studies, documents and reports published in recent years which have singled out the teacher as the

${ }^{3}$ The milestones often cited in literature include the first World Conference on Education for All in Jomtein, Thailand (UNESCO, 1990), the Salamanca Statement and Framework for Action on Special Needs Education (UNESCO, 1994), and the Dakar Framework for Action, Education for All: Meeting our Collective Commitments at the World Education Forum in Dakar, Senegal (UNESCO, 2000). 
key figure to bring about change and have warranted for a greater investment in teacher education and competence development (Aiello et al., 2014; Avramidis \& Norwich, 2002; EADSNE, 2009, 2010; European Commission, 2015; OECD, 2015), despite the stringent budgets on education ${ }^{4}$. Further, among the guidance given regarding teacher capacity building, there seems to be a shared agreement that "the principles of inclusion should be built into teacher training programmes [...] [and concentrate on] attitudes and values not just knowledge and skills" (WHO, 2011, p. 222; EADSNE, 2009, 2010; OECD, 2015). This is also confirmed in empirical findings, as outlined in the following sections of this article.

\section{Research Questions}

On the basis of such reflections, the following research questions were raised: Which theoretical frameworks can inform research on teacher decision making to act and bring about change? What tools have been developed to measure the predictive levels of such variables? Which are the key variables that may impinge on teachers' willingness to adopt innovative teaching strategies?

This article attempts to provide a wide span of data available in literature to date to help answer these three questions. Provided that there has been exceptional interest around these issues over the past decades and this research mainly aimed at gaining an initial view on the studies and the evidence available, it cannot be considered comprehensive or systematic. The scope of this paper is mainly that of offering researchers in education a starting point to the theories supporting research, the methods and instruments used to measure possible correlations and predictions on behavioural intention and the variables affecting teachers' willingness to act.

\footnotetext{
${ }^{4}$ Spending cuts in education in the EU as a whole started in real terms in 2011, recording a $3.2 \%$ fall since 2010 . Italy recorded a decrease of its education budget for six consecutive years (2008-2013), in spite of the continuously growing youth cohorts. Among the other 10 member states who have decreased spending, Spain, Ireland, the Netherlands, the UK, Finland and Portugal, cut education expenditure for three consecutive years (European Commission, 2015).
} 


\section{Theoretical Frameworks Supporting Research on Teacher Agency}

In studying the determinants that influence agency, the psychological (Ajzen, 1988; Bandura, 1986), sociological (Bourdieu, 1977; Emirbayer \& Mische, 1998) and, more recently, neuroscience (Berthoz, 2003, 2012) research have proven to be indispensable to guide the search for reasons why people do or do not engage in certain behaviours, identify the indicators that can be monitored and measured, help pinpoint what planners need to know before developing interventions, and suggest how to devise programmes that reach target audiences and have an impact (Rimer \& Glanz, 2005). Although these theories are comprehensive in their own right and stem from different streams of research, they share some common denominators. Firstly, they are all "rooted in an agentic perspective in which people function as anticipative, purposive and self-evaluating proactive regulators of their motivation and actions" (Bandura \& Locke, 2003, p. 87). Secondly, decisions to act take into account personal, social and cultural factors. Therefore agency is not considered as a capacity or competence, but as "integrated courses of action" (Bandura, 1982, p. 122) that are generated from a "configuration of influences from the past, orientations towards the future and engagement with the present. [Emirbayer \& Mische (1998)] refer to these three dimensions as the iterational, the projective and the practical-evaluative dimension, respectively" (Biesta, Priestley \& Robinson, 2015, p. 626; emphasis in original).

Biesta et al. (2005) highlighted that sociological studies investigating teacher agency, defined as the activities of teachers in schools, are still limited. Yet there is a growing body of literature from the psychological and educational fields on how beliefs, concerns, teacher efficacy, self-efficacy, attitudes, perceived behaviour control, and context-oriented variables and constructs such as volitional control and subjective norms influence behaviour and agency. Among the theories which have often been applied, especially in investigating the variables that influence teachers' willingness to implement inclusive practices, are Bandura's Social Cognitive Theory (Bandura, 1986) and the Theory of Planned Behaviour (Ajzen, 1988). A brief overview of the theories follows.

\section{Social Cognitive Theory}

The underpinning assumption of Social Cognitive Theory (Bandura, 1986) is the fact that there is a constant dynamic interplay between personal (including beliefs, self-perceptions and expectations), behavioural and 
environmental factors and it is posited that individual behaviour determines and is determined by this triadic reciprocal causation. In other words, agency anticipates behaviour as a result of environmental influences, behaviour and internal personal factors such as cognitive, affective, and biological processes. Therefore, "persons are neither autonomous agents nor simply mechanical conveyers of animating environmental influences[...]" and "[a]ny account of the determinants of human action must [...] include self-generated influences as a contributing factor" (Bandura, 1989, p. 1175). When dealing with complex scenarios, as are inclusive classrooms (Sibilio, 2014), these elements impinge on what strategies the teacher chooses to put into practice, the effort invested into implementing them, and the persistence in the long term (Putman, 2012).

Fundamental and influential to human agency is the construct of selfefficacy (Bandura, 1982, 1989, 1997), "cognitive mediators of action" (Bandura, 1982, p. 126) which refer to one's beliefs in his or her capabilities in organizing and executing the courses of action required to reach a certain goal (Bandura, 1997). This is because self-efficacy does not depend on the competencies one possesses, but "what you believe you can do with what you have under a variety of circumstances" (Bandura, 1986, p. 37). This selfreferent judgement, whether precise or inaccurate, depends on: "performance attainments, vicarious experiences of observing the performances of others, verbal persuasion and allied types of social influences that one possesses certain capabilities, and psychological states from which people partly judge their capability, strength and vulnerability" (Bandura, 1982, p. 126). Figure 1 summarises the complex interplay between factors and behaviour and the underlying processes and sources of information linked with each factor.

The extensive studies of this construct in the field of education led to the development of the construct of teacher efficacy, which includes both the construct of self-efficacy and of outcome efficacy. Hence it encapsulates two components: personal teacher efficacy (PTE), which refers to a teacher's belief in his/her ability to bring about change in a student and general teacher efficacy (GTE) which is pertinent to a teacher's belief that external (environmental) influences can be controlled by good teaching (Gibson \& Dembo, 1984). As self-efficacy, teacher efficacy is a context-specific construct (Bandura, 1982; Tschannen-Moran \& Woolfolk Hoy, 2001) and may well vary across participants (Ross, Cousins \& Gadalla, 1996) and student groups (Raudenbuch, Rowen \& Cheong, 1992). For this reason, literature suggests that teacher efficacy should be measured in relation to specific teaching tasks in contextual classrooms (Tschannen-Moran \& Woolfolk Hoy, 2001) such as the ability to plan inclusive activities or manage classroom behaviour. Evidence that self and teacher efficacy are stable and vital indicators of various actions linked to effective inclusive education is provided in the thorough literature review 
conducted by Tschannen-Moran, Woolfolk Hoy and Hoy in 1998 who propose an integrated model which "weaves together both conceptual strands $[\ldots]$ and new areas for research" (p. 227). This model is based on the assumption that influencing efficacy beliefs are mastery experience, physiological arousal, vicarious experience, and verbal persuasion; the four sources of information outlined by Bandura $(1986,1997)$. Similar to Gibson \& Dembo's (1984) GTE and PTE, two dimensions are identified: analysis of teaching task and assessment of personal teaching competence. Figure 1, below, presents the cyclical nature of teacher efficacy as theorised by Tschannen-Moran et al. (1998, p. 228).

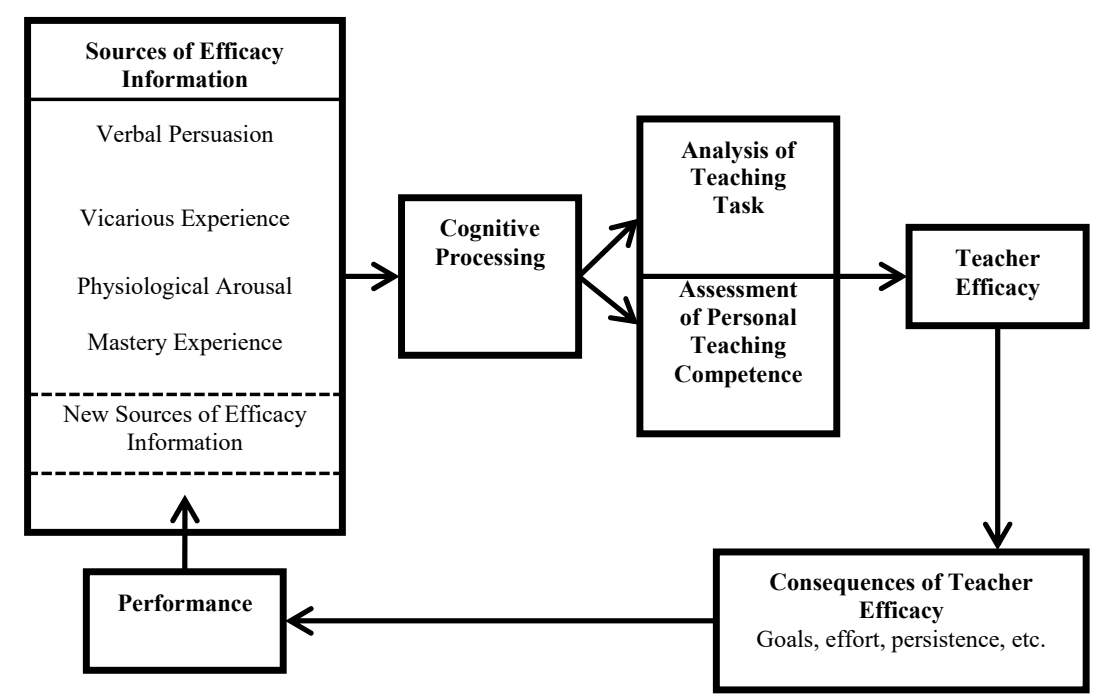

The Theory of Planned Behaviour

Figure 1. The cyclical nature of teacher efficacy

Ajzen's Theory of Planned Behaviour (TPB) (1988) is a revisited model of the Theory of Reasoned Action (TRA) (Fishbein and Ajzen, 1975; Ajzen \& Fishbein, 1980). The rationale behind TRA and, later, TPB was that between one's attitude and actions stood a mediating variable which was most predictive of behaviour: the intention to act out the behaviour. On the basis of the assumption that humans are rational beings that systematise the information available before choosing a course of action, and that people evaluate the outcome and impact of their actions before deciding whether to engage in certain behaviours, Fishbein and Ajzen (1975) proposed the TRA. Yet, following the application of this theory, it became evident that a key variable was missing. Ajzen (1988) proposed that besides attitude toward the behaviour 
and subjective norm, which were retained from the former TRA model (Fishbein and Ajzen, 1975; Ajzen \& Fishbein, 1980), intentional behaviour and behaviour itself are also a function of perceived behaviour control.

Attitude toward the behaviour is "personal in nature" (Ajzen, 2005, p. 117) and refers to "the individual's global positive or negative evaluations of performing a particular behaviour" (Armitage \& Conner, 2001, p. 474). The more positive the attitude toward a particular behaviour is, the stronger are the intentions to perform that behaviour. Attitude is a hypothetical construct that can be defined as "a disposition to respond favourably or unfavourably to an object, person, institution, or event" (Ajzen, 1988 p. 4), which is more malleable in nature than personality traits. Being inaccessible to direct observation, this construct must be inferred from measurable verbal and nonverbal responses that can be categorised in three sub groups: cognition, affect and conation (Ajzen, 1988). Expressions of verbal responses of cognitive nature refer to beliefs, convictions and prejudices, affective verbal responses are linked to sentiments, prejudices and stereotypes, whereas expressions of behavioural inclinations, intentions, commitments and behaviour towards a specific situation are examples of conative verbal responses. Research on attitudes usually resorts to this form of responses, as responses of a nonverbal kind, such as facial expressions and bodily reactions are more difficult to assess and the information they provide is usually more indirect (Ajzen, 1988).

Subjective norm "reflects social influence" (Ajzen, 2005, p. 117) and is weighted by normative beliefs about the behaviour and the motivation to comply. This antecedent "refers to the individual's perceptions of general social pressure to perform (or not to perform) the behaviour" (Armitage \& Conner, 2001, p. 474). The more individuals perceive that significant others approve of the behaviour, the more likely they are to behave in that manner, and vice versa.

Perceived Behavioural Control (PBC) deals "with issues of control" (Ajzen, 2005 , p. 117) and influences behaviour directly and indirectly via behavioural intention (See Figure 2). This factor "provides information about the potential constraints on action as perceived by the actor, and is held to explain why intentions do not always predict behaviour" (Armitage \& Conner, 2001, p. 472). Ajzen (1988) introduced this variable on the assumption that PBC "would allow prediction of behaviour that were not under volitional control" (Armitage \& Conner, 2001, p. 472). In fact, the relative importance of these three conceptually independent factors on intentions and behaviour "may vary across behaviours and situations" (Ajzen, 1991, p. 188). Ajzen (1991) associated PBC with the construct of self-efficacy, claiming that they can be considered compatible. However, Bandura (1992) held contrasting opinions, postulating that they are different concepts because self-efficacy focuses on cognitive 
internal control factors while $\mathrm{PBC}$ is more general and includes external factors. In their meta-analytic review on the TPB, Armitage and Conner (2001) found that "self-efficacy and PBC have a comparable level of correlation with both intention (both $\mathrm{rs}=.44)$ and behaviour $(\mathrm{rs}=.35)$ and .40 , respectively)" (p. 483), thus concluding that "are both useful predictors" (p. 487) for the two variables. The authors added that "self-efficacy is more clearly defined and operationalized than is PBC (cf. Bandura, 1997), which consists of mixed measures" (p. 487) and hence "may be the preferred measure of "perceived control' within the TPB" (p. 488).

Underpinning the three antecedents to behavioural intention (Attitude toward Behaviour, Subjective Norm and PBC) are corresponding beliefs whose strength can determine whether an individual engages in behaviour or otherwise. Beliefs can be defined as the cognitive and mental component, expressing an individual's opinion which does not necessarily represent reality, but a subjective reality (Aiello et al, 2016). The beliefs influencing Attitude toward Behaviour are beliefs about the outcome of the behaviour, those affecting Subjective Norm are normative beliefs, while control beliefs impinge on $P B C$.

Ajzen (2005) further acknowledged that a series of background factors can influence an individual's beliefs. He grouped these factors in three categories: personal characteristics, social and demographic variables, and past experience and exposure to other sources of information. Personal characteristics include general attitudes, personality traits, values, emotions and intelligence. Examples of social and demographic variables are age, gender, race, ethnicity, education, income and religion, while examples of sources of information refer to experience, knowledge and media exposure (Ajzen, 2005, p. 135). Thus, the study of various combinations of predictor variables can be conceptualised within the TPB framework. Figure 2 illustrates Ajzen's TPB model (2005) applied to a teacher's possible reasoning behind the intention of adopting a method, such as Episodes of Situated Learning (ESL) (Rivoltella, 2015) in lesson planning, to promote inclusive education.

The TPB has been widely used in an array of fields from health behaviour change (Di Clemente, Crosby \& Kegler, 2009) to consumer behaviour (Shepherd, Sparks \& Guthrie, 1995) and disability and inclusive practices (for example, Ahmmed, Sharma \& Deppeler, 2013; Sharma \& Jacobs, 2016; Ahsan, Deppeler \& Sharma, 2013; Cinti, 2004; Kuyini and Desai, 2007; Theodorakis, Bagiatis \& Goudas, 1995). In Italy, very little literature is available on the application of the theory especially within the field of education, and no research was found that had used the TPB to study the relationships between variables impinging on the implementation of inclusive practices. 


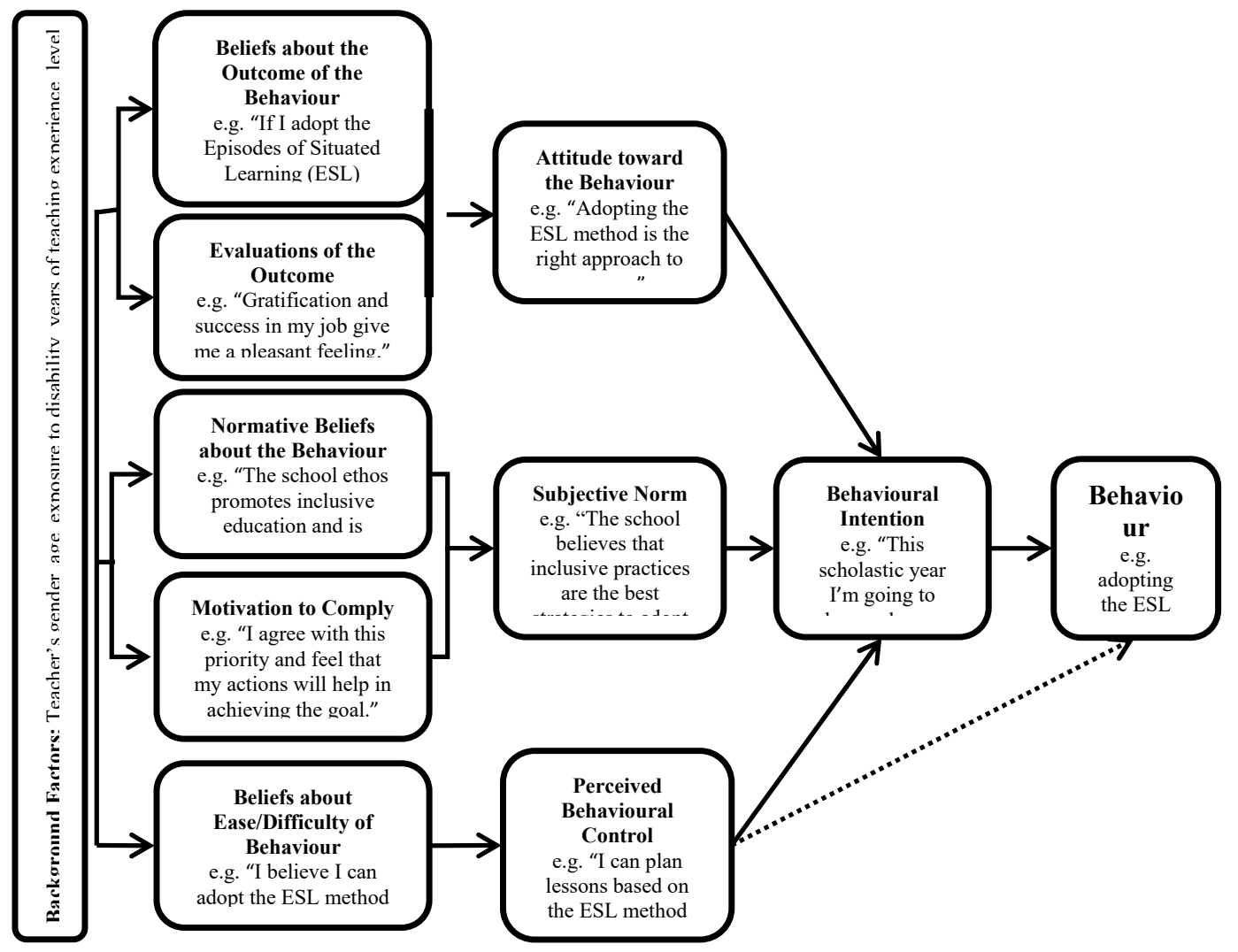

Figure 2. Teacher's willingness to adopt the Episodes of Situated Learning Method (Rivoltella, 2015) in lesson planning applied to the TPB model (Ajzen, 1988).

\section{Scales to Measure Factors Influencing Teachers' Willingness to Implement Inclusive Practices}

To date, most of the research conducted on this theme has availed of multidimensional self-reporting questionnaires with 4 to 9-point Likert scales; an approach often adopted to measure complex concepts that cannot be observed directly (Fiorucci, 2014). In the study conducted by Fiorucci (2014), a long list of scales to measure teacher attitudes was drawn. Also, in the literature reviews conducted by Tschannen-Moran et al. (1998), scales measuring teacher self efficacy and teacher efficacy were identified. Other scales measuring an array 
of variables from beliefs to concerns and knowledge about inclusive education were found from the literature review conducted by the authors.

Table 1 (Appendix A) includes only those scales designed to measure teacher-related factors that are predictive of willingness to implement inclusive practices. Hence, scales specifically designed to collect data from parents, students, heads of school and other stakeholders have been ignored. With regards to the term 'inclusive practices' or 'inclusion', this definitely does not always have the same meaning throughout all the contexts the scales were applied in. Considering the vast research in the area, the selection of the scales presented cannot be considered comprehensive. They are presented in chronological order.

As can be observed in the table, research on this phenomenon has been undertaken since the 70s, even if at the time inclusion was not as is understood today, and the quest to create a scale that can predict teachers' actions has intrigued many. In the choice of which scale to use, the criteria that one should bear in mind are:

1. Construct validity;

2. Brevity;

3. Internal consistency as a measure of reliability - high intercorrelations among items indicate they measure the same construct;

4. Unidimensionality;

5. Simplicity - in terms of ease of understanding and answering (Saloviita, 2015).

Among the scales used, only few meet all the requirements. Length varies widely, reaching over 50 items. This is an important factor to keep in mind considering that often a combination of these scales is administered in addition to a series of questions to collect demographic variables. Where internal consistency using Cronbach's alpha for the scales was available, this value was always higher than .70, the mark below which scales would need to be used with care (DeVellis, 2003). The majority of the scales were not unidimensional while the characteristic of simplicity was maintained.

\section{Salient Results on Variables Influencing Teachers' Willingness to Implement Inclusive Practices in Italy and Overseas}

Following the brief overview of two of the most influential theories on predicting human behaviour and the scales produced so far to study the variables impinging on the decision to act, it becomes all the more evident that the variables at play are plenty, they are interweaved, and their measurement is 
not always so straightforward. Moreover, as previously outlined, providing overarching generalizable conclusions on the variables impacting behaviour is an arduous task due to the dissimilarities in educational systems and sociopolitical contexts; the lack of a shared understanding of inclusive practices between and within countries; the different periods when the studies were conducted; and the variations in methodologies and data-collection tools.

Starting off with the data available regarding the Italian context, studies conducted on a national level concentrated mainly on attitudes and efficacy. A study involving 3230 teachers and other professional figures in Northern Italy found that the teachers interviewed had high percepts of efficacy and more than $90 \%$ had a positive attitude towards integration ${ }^{5}$ (Ianes, Demo \& Zambotti, 2010). This confirmed concurrent research on teaching in integrated classrooms carried out by Fondazione Giovanni Agnelli (2010) which involved 7700 beginning teachers in various regions in Italy. This study provided evidence that $76.5 \%$ of those interviewed had a high sense of efficacy and $91.6 \%$ believed that through integration all children benefited and $90.5 \%$ agreed that integration would help them to grow professionally (Fondazione Giovanni Agnelli, 2010). Similar results on teacher efficacy were obtained in the Teaching and Learning International Survey (TALIS) (OECD, 2009, 2014a, $2014 \mathrm{~b}$ ) in relation to teachers' feelings of job satisfaction and various demographic variables. Data from the second edition of the large-scale study conducted in 2013 (OECD, 2014a) showed that $87 \%$ of Italian teachers teaching in lower secondary schools believe in their ability to motivate students who do not show interest in school. Moreover, nearly all the teachers (98\%) feel capable of orienting students to believe in their own capabilities to reach good results. Interestingly, the percentages for both items are over $10 \%$ higher than TALIS-countries average.

The study carried out by Biasi, Domenici, Capobianco and Patrizi (2014) provided further confirmatory results. They found that the levels of selfefficacy among the 200 teachers employed in primary and secondary schools were quite high for all three factors of the TSES scale (Tschannen-Moran \& Woolfolk Hoy, 2001). Also, latest studies conducted by Aiello et al. (2016) found that in-service generalist and learning support teachers have high levels of efficacy and positive attitudes towards inclusive practices. Although no significant differences emerged for these two variables between primary and secondary school teachers, the former had higher levels of concern. This is in contrast with Lopes, Monterio, Sil, Rutherford \& Quinn's (2004) findings who

\footnotetext{
${ }^{5}$ Although the term integration is used, some of the questionnaire items referred to inclusive practices and hence the study was considered worth citing.
} 
posited that teachers' feelings of efficacy in managing behaviour are lower as the years levels at school progress.

As with the studies conducted in Italy, a lot of the research carried out on an international level link teachers' attitudes and efficacy, often confirming that levels of self or teacher efficacy are positively correlated to attitudes towards inclusion (Malinen et al., 2012; Savolainen et al., 2012; Sharma \& Sokal, 2015; Weisel \& Dror, 2006). Evidence from research has shown that teachers with positive attitudes tend to adopt inclusive practices more than teachers with apprehensive attitudes (Ahsan et al. 2013; Sharma, Forlin \& Loreman, 2008; Sharma, Moore \& Sonawane, 2009), which, in turn, have an effect on classroom climate and students' performance and affect the teachers' commitment to implementing inclusive practices in the long term (Avramidis \& Norwich, 2002; Jordan, Schwartz, \& McGhie-Richmond, 2009; Putman, 2012).

Other variables such as intentions, beliefs, concerns, and various background variables are often investigated in light of teacher efficacy levels and teacher attitudes. For example, in studying the relation between teacher efficacy, attitudes and teacher intentions of around 600 Indian and Australian in-service educators, Sharma \& Jacobs (2016) found that the higher the efficacy and the more positive the attitude towards inclusion, the more their intention to teach in inclusive classrooms is. The qualitative research study conducted by Sharma \& Sokal (2015) in Canada also confirmed that teachers engaging in inclusive behaviour had lower levels of concern and positive attitudes.

Teacher concerns have been of interest since the late $70 \mathrm{~s}$ and the three categories, academic, administrative and pedagogical concerns, identified by Larivee \& Cook (1979) on mainstreaming are still pertinent today. Cornoldi, Terreni, Scruggs \& Mastropieri (1998) noted dissatisfaction with the time, training, personnel assistance, and other resources that were provided for inclusion programmes. The results of the study by Round, Subban \& Sharma (2015) revealed that Victorian secondary school teachers felt that inclusive practices are an additional burden to their already heavy workload and that the school would not have the adequate resources to support inclusive practices. On the other hand, levels of concern decreased as the degree of confidence increased. Similar correlations were observed in studies conducted by Agbenyeva in Ghana in 2007. Meanwhile, the areas of concern identified by Forlin, Keen and Barrett (2008) in their study among Western Australian teachers were related to the pupils' behaviour and the teachers' perception of their own competence. Remarkably, professional development did not reduce these concerns and more experienced teachers even expressed more concerns. On the contrary, the study conducted by Sharma \& Nuttal (2015) showed that a university teacher training course reduced concern ratings about acceptance of 
students with a disability by others, concerns about the impact of inclusive practices on academic standards, and on teachers' workloads.

The research conducted by Ahmmed et al. (2013) found that Perceived School Support, a subjective norm in TPB, was the strongest predictor variable, influencing teachers' intentions more than attitudes, teacher efficacy, teachers' age and teaching experience. Studies concentrating on levels of teacher efficacy towards inclusive education showed that teachers' self perceptions on competence were influenced by the type of training offered by the institution, the level of knowledge regarding legislation and policies on inclusion, and teaching experience and personal interaction with people with disabilities (Sharma, Loreman \& Forlin, 2011; Loreman, Sharma \& Forlin, 2013; Sharma, Shaukat \& Furlonger, 2014).

As regards background factors, results have often been contradicting. In their study, Ahmmed et al. (2013) found that teachers' age and length of teaching experience were statistically significant in predicting teachers' intentions. Younger teachers, but with same experience, were more open to inclusion than older colleagues. However, teachers with more years of experience were more willing than their colleagues with fewer years of experience. A study conducted by Malinen et al. (2013) using a sample of 1911 in-service teachers from China, Finland and South Africa identified significant country-specific findings. In fact, the results from South Africa provided strong evidence of the impact of culture and context on teacher efficacy and the potential success or otherwise of inclusive practices.

\section{Discussion and Conclusions}

While taking into consideration that studies on human behaviour are constantly evolving and they are of interest for different scientific domains, some common denominators that can help to better understand and predict action can already be pinpointed. As outlined in the second part of this article, agentic theories are suitable theoretical frameworks, as they consider the individual as a complex adaptive system (Berthoz, 2012; Sibilio, 2014) with unique demographic variables, beliefs, values, concerns, attitudes, personality traits, perceived efficacy, experience, knowledge, intentions and objectives (Ajzen, 1988; Bandura, 1986; Bourdieu, 1977), who lives and works with other individuals within larger complex adaptive systems and among which there is a constant interplay of influences. Hence, as posited by Bandura (1986), the decision to take action and sustain it is a function of the triadic reciprocal causation between behaviour, personal and environmental factors. Further, agency is of an emergent interactive type (Bandura, 1982) that is preceded by 
the act (Berthoz, 2012), or intentional behaviour (Ajzen, 1988) - "the act with its intentionality, its memory of the past, its projection onto the future, the specificity of what interests us in the world as a function of our Umwelt" (Berthoz, 2012, p. 206). Grounding research on such frameworks not only helps to provide data to support these theories, but also to avoid the risk of reductionist conclusions of a cause-effect type when investigating human and teacher agency.

In reviewing the literature available internationally, it is evident that quantitative research is predominantly used, although some examples of qualiquantitative studies have been conducted providing fruitful information for reflection (for example Ahsan et al., 2013). Studies reviewed tended to focus on whether the correlations exist more than the why, a common characteristic of quantitative research. One other limitation of such instruments is that "there is always the danger of the respondents giving socially desirable answers that have little or no correspondence with their everyday behaviour" (Avramidis \& Norwich, 2002, p. 143; Armitage \& Conner, 2001). Therefore, besides concentrating on the predictive element of such variables and the correlation among them, there is a need to examine more deeply the cognitive, affective and conative aspects, through the use of qualitative research methods such as focus groups, interviews and the use of professional development reflective journals (Pace \& Aiello, 2015). These methods may well aid in providing data on the cultural meaning attributed to roles, educational purpose, expectations and significant others influencing one's beliefs. This could be achieved through longitudinal quali-quantitative case studies "to examine the transformation across time and allow for a more thorough investigation in order to better be able to understand the complexities of inclusion and provide directions for change or continuity of provision as appropriate" (Avramidis \& Norwich, 2002, p. 144). Moreover, research needs to expand on other variables, which haven't yet received as much importance. Some interesting work worth mentioning as an example is the study carried out by Evers, Browers and Tomic (2002, p. 227) who included a burnout inventory for teachers to test whether "a negative attitude towards new instructional practices relate[d] positively to [the teachers'] level of burnout and that their selfefficacy beliefs regarding implementation of the practices and coping with stress involved in this relate negatively to their burnout levels".

Despite the copious research on variables affecting teachers' willingness to implement inclusive practices, very little research has been conducted in Italy to date. This country can surely offer valid insight into what factors impinge on the successful and sustainable implementation of inclusive practices, considering its longstanding pedagogical history and a consolidated political and educational infrastructure that has been in place for decades. 
In connection with the authors' research interests in teacher agency that stemmed from studies on the science of teaching (didactics) rooted in a bioeducational perspective (Frauenfelder, 1983, 1994) and which, over time, sought possible allegiances with other research strands on didactics, mainly enactivism (Rossi, 2011), neurodidactics (Rivoltella, 2012, 2014), and simplex didactics (Sibilio, 2014; Frauenfelder, Rivoltella, Rossi \& Sibilio, 2013), have undertaken this search on a theoretical and practical level. This article presented the first phase of the research, which aimed at providing insight on teacher agency and on the development of validated tools for research in didactics in Italy. So far, two of the scales, the TEIP and the SACIE-R scales have been translated, administered and validated in Italy with a group of inservice teachers (Aiello et al., 2016). Another three scales, the CIES (Sharma \& Desai, 2002), AIS and ITICS (Sharma \& Jacobs, 2016) have been translated, administered, and data inputting is underway with the intention of providing Italian versions of the scales to get a snapshot of what factors influence Italian pre-service and in-service generalist, subject and learning support teachers' willingness to implement inclusive practices and in turn provide information for teacher education planning.

\section{References}

Agbenyega, J. (2007). Examining teachers' concerns and attitudes to inclusive education in Ghana. International Journal of Whole Schooling, 3(1), 41-56.

Ahmmed, M. Sharma, U., \& Deppeler, J. (2013). Variables affecting teachers' intentions to include students with disabilities in regular primary schools in Bangladesh. Disability and Society, May 2013. doi:10.1080/09687599.2013.796878.

Ahsan, M.T., Deppeler, J., \& Sharma, U. (2013). Predicting pre-service teachers' preparedness for inclusive education: Bangladeshi pre-service teachers' attitudes and perceived teaching efficacy for inclusive education. Cambridge Journal of Education, 43(4), 517-535.

Aiello, P., Corona, F., \& Sibilio, M. (2014). A proposal for a feasible evolution of the role of the support teacher in Italy. Italian Journal of Special Education for Inclusion, 2(2), 21-34.

Aiello, P., Sharma, U., Dimitrov, D.M., Di Gennaro, D.C., Pace, E.M., Zollo, I., \& Sibilio, M. (2016). Indagine sulle percezioni del livello di efficacia dei docenti e sui loro atteggiamenti nei confronti dell'inclusione. L'Integrazione Scolastica $e$ Sociale, 15(1), 64-87.

Ajzen, I. (1988). Attitudes, Personality and Behavior. Milton Keynes: Open University Press.

Ajzen, I. (1991). The theory of planned behavior. Organizational Behavior and Human Decision Processes, 50, 179-211. 
Ajzen, I. (2005). Attitudes, Personality and Behavior (2 ${ }^{\text {nd }}$ Ed.). New York: Open University Press.

Ajzen, I., \& Fishbein, M. (1980). Understanding Attitudes and Predicting Social Behavior. Englewood Cliffs, NJ: Prentice-Hall.

Alvarez McHatton, A., \& McCray, E. D. (2007). Inclination toward inclusion: perceptions of elementary and secondary education teacher candidates. Action in Teacher Education, 29, 25-32. http://dx.doi.org/10.1080/01626620.2007.10463457.

Antonak, R. F., \& Larrivee, B. (1995). Psychometric analysis and revision of the opinions relative to mainstreaming scale. Exceptional Children, 62, 139-149.

Armitage, C.J. \& Conner, M. (2001). Efficacy of the theory of planned behaviour: A meta-analytic review. British Journal of Social Psychology, 40, 471-499.

Armstrong, A.C., Armstrong, D., \& Spandagou, I. (2010). Inclusive Education: International Policy and Practice. London: Sage.

Ashton, P.T., Olejnik, S., Crocker, L., \& McAuliffe, M. (1982, April). Measurement problems in the study of teachers' sense of efficacy. Paper presented at the Annual Meeting of the American Educational Research Association, New York.

Avramidis, E., \& Norwich, B. (2002). Teachers' attitudes toward integration/inclusion: A review of the literature. European Journal of Special Needs Education, 17(2), 129-147. doi:10.1080/08856250210129056.

Bailey, J. (2004). The validation of a scale to measure school principals' attitudes toward the inclusion of students with disabilities in regular schools. Australian Psychologist, 39(1), 76-87. doi:10.1080/00050060410001660371.

Bandura, A. (1982). Self-efficacy mechanism in human agency. American Psychologist, 37(2), 122-147.

Bandura, A. (1986). Social Foundations of Thought and Action: A Social Cognitive Theory. Englewood Cliffs, NJ: Prentice Hall.

Bandura, A. (1989). Self-efficacy mechanism in human agency. American Psychologist, 44(9), 1175-1184.

Bandura, A. (1992). On rectifying the comparative anatomy of perceived control: Comments on 'Cognates of personal control'. Applied and Preventive Psychology, $1,121-126$.

Bandura, A. (1997). Self-efficacy: The Exercise of Control. New York: W. H. Freeman and Company.

Bandura, A., \& Locke, E.A. (2003). Negative self-efficacy and goal effects revisited. Journal of Applied Psychology, 88(1), 87-99.

Bender W.N., Vail C.O., \& Scott K. (1995). Teachers' attitudes toward increate mainstreaming: Implementing effective instruction for students with Learning disabilities. Journal of Learning Disabilities, 10(2), 87-94.

Berryman J. D., Neal W. R. (1980). The cross validation of the Attitudes Toward Mainstreaming Scale (ATMS). Education and Psychological Measurement, 40, 467-474.

Berthoz, A. (2003). La Scienza della Decisione. Paris: Odile Jacobs [Italian Translation by Federica Niola].

Berthoz, A. (2012). Simplexity: Simplifying Principles for a Complex World. USA: Yale University Press. [English Transaltion by Giselle Weiss]. 
Biasi V., Domenici, G., Capobianco R., \& Patrizi. N. (2014). Teacher efficacy scale (Scala sull'Autoefficacia del Docente - SAED): Adattamento e validazione in Italia. ECPS Journal, 10, 485-509. doi:10.7358/ecps-2014-010-bias.

Biesta, G., Priestley, M. \& Robinson, S. (2015). The role of beliefs in teacher agency. Teachers and Teaching. Theory and Practice, 21(6), 624-640. doi:10.1080/13540602.2015.1044325.

Booth, T. (2011). Index for Inclusion - Developing Learning and Participation in Schools. UK: Centre for Studies on Inclusive Education [CSIE].

Bourdieu, P. (1977). Outline of a Theory of Practice. London: Cambridge University Press [English Translation by Richard Nice].

Chiappetta Cajola, L.C., \& Ciraci, A.M. (2013). Didattica inclusiva: Quali competenze per gli insegnanti?. Roma: Armando Editore.

Cinti, M.E. (2004). Il controllo comportamentale percepito in adolescenti di scuola superiore: Un'applicazione della Teoria del Comportamento Pianificato. QUALE Psicologia, 24, 24-46.

Cochran, H.K. (1998). Differences in teachers' attitudes toward inclusive education as measured by the scale of teachers' attitudes toward inclusive classrooms (STATIC). Paper presented at the Annual Meeting of the Mid-Western Educational Research Association, Chicago, IL. October, pp. 14-16.

Commission of the European Communities (2007). Communication from the Commission to the Council and the European Parliament: Improving the Quality of Teacher Education 3/08/2007. Retrieved from http://eur-lex.europa.eu/legalcontent/EN/TXT/?uri=CELEX\%3A52007DC0392 on 25 January, 2016.

Cornoldi, C., Terreni, A., Scruggs, T., \& Mastropieri, M. (1998). Teacher attitudes in Italy after twenty years of inclusion. Remedial and Special Education, 19, 350-356.

Cullen, J.P., Gregory, J.L., \& Noto, L.A. (2010). The teacher attitudes toward inclusion scale (TATIS). Paper presented February 11, 2010 at the meeting of the Eastern Educational Research Association. Retrieved from http://eric.ed.gov/?id¹/4ED509930.

D’Alessio, S., Medeghini, R., Vadalà, G., \& Bocci, F. (2015). L'approccio dei Disability Studies per lo sviluppo delle pratiche scolastiche inclusive in Italia, in R. Vianello and S. Di Nuovo (Eds.) Quale Scuola Inclusiva in Italia? Oltre le Posizioni Ideologiche: Risultati della Ricerca (pp. 151-180). Trento: Erickson.

de Anna, L. (2014), Pedagogia speciale. Integrazione e inclusione, Roma, Carocci.

DeVellis, R.F. (2003). Scale Development: Theory and Applications. Newbury Park, CA: Sage.

Di Blas, N \& Ferrari, L. (2014). What teachers think about inclusion: data from a largescale explorative survey. Journal of Theories and Research in Education, 9(2), 1-22.

Di Clemente, R.J., Crosby, R.A., \& Kegler, M.C. (Eds.) (2009). Emerging Theories in Health Promotion Practice and Research. San Francisco: Wiley.

EADSNE [European Agency for the Development of Special Needs Education]. (2009). Key Principles for Promoting Quality in Inclusive Education Recommendations for Policy Makers. Denmark: Author.

EADSNE. (2010). Teacher Education for Inclusion - International Literature Review. Denmark: Author. 
Emirbayer, M. \& Mische, A. (1998). What is agency? American Journal of Sociology, 103, 962-1023.

European Commission (2015). Education and Training Monitor 2015. Luxembourg: Publications Office of the European Union. Retrieved from: ec.europa.eu/education/monitor.

Evers, W.J.G., Brouwers, A., \& Tomic, W. (2002). Burnout and self-efficacy: A study on teachers' beliefs when implementing an innovative educational system in the Netherlands. British Journal of Educational Psychology, 72, 227-243.

Fiorucci, A. (2014). Gli atteggiamenti degli insegnanti verso l'inclusione e la disabilità: uno sguardo internazionale. Italian Journal of Special Education for Inclusion, II(1), 53-66.

Fishbein, M. \& Ajzen, I. (1975). Belief, Attitude, Intention and Behaviour: An Introduction to Theory and Research. Reading, MA: Addison-Wesley.

Fondazione Giovanni Agnelli (2010). Rapporto sulla Scuola in Italia. Roma-Bari: Laterza.

Forlin C., Earle, C., Loreman T., \& Sharma, U. (2011). The Sentiments, Attitudes and Concerns about Inclusive Education Revised (SACIE-R) scale for measuring teachers' perceptions about inclusion. Exceptionality Education International, 21(3), 50-65.

Forlin, C., Keen, M. \& Barrett, E. (2008). The Concerns of Mainstream Teachers: Coping with Inclusivity in an Australian Context. International Journal of Disability, Development and Education, 55(3), 251-264.

Frauenfelder, E. (1983). La prospettiva educativa tra biologia e cultura. Napoli: Liguori.

Frauenfelder, E. (1994). Pedagogia e Biologia. Una possibile “alleanza”. Napoli: Liguori.

Frauenfelder, E. Rivoltella, P.C., Rossi, P.G., \& Sibilio, M. (2013). Bio-education, simplexity, neuroscience and enactivism. A new paradigm? Education Sciences \& Society, 4(1), 11-25.

Gibson, S. \& Dembo, M. (1984). Teacher efficacy: A construct validation. Journal of Educational Psychology, 76(4), 569-582. doi:10.1037/0022-0663.76.4.569.

Hodkinson, A. (2011). Inclusion: A defining definition? Power and Education, 3(2), 179-185. http://dx.doi.org/10.2304/power.2011.3.2.179

Ianes D., Demo H., \& Zambotti F. (2010). Gli insegnanti e l'integrazione: Atteggiamenti, opinioni e pratiche. Trento: Erickson.

Jordan, A., Schwartz, E., \& McGhie-Richmond, D. (2009). Preparing teachers for inclusive classrooms. Teaching and Teacher Education, 25(4), 535-542.

Kuyini, A.B. \& Desai, I. (2007). Principals' and teachers' attitudes and knowledge of inclusive education as predictors of effective teaching practices in Ghana. Journal of Research in Special Educational Needs, 7(2), 104-113.

Kuyini, A.B. \& Desai, I. (n.d.). The Theory of Planned Behaviour as a framework for predicting and implementing effective inclusive practices. Innovations in Inclusive School Development Conference Proceedings. Retrieved from: http://bern.library.nenu.edu.cn/upload/soft/0-article/+0001/2CPP2.pdf. 
Larrivee B., Cook L. (1979). Mainstreaming: A study of the variables affecting teacher attitude. The Journal of Special Education, 13(3), 315-324.

Lopes, J.A., Monterio, I., Sil, R.B., Rutherford, R.B., \& Quinn, M.M. (2004). Teachers' perceptions about teaching problem students in regular classrooms. Education and Treatment of Children, 27(4), 394-419.

Loreman, T., Earle, C., Sharma, U., \& Forlin, C. (2007). The development of an instrument for measuring pre-service teachers' sentiments, attitudes and concerns about inclusive education. International Journal of Special Education, 22(2), 150159.

Loreman, C., Sharma, U., \& Forlin, C. (2013). Do pre-service teachers feel ready to teach in inclusive classrooms? A four country study of teaching self-efficacy. Australian Journal of Teacher Education, 38(1), 27-44.

Mahat, M. (2008). The Development of a Psychometrically-Sound Instrument to Measure Teachers' Multidimensional Attitudes toward Inclusive Education. International Journal of Special Education, 23(1), 82-92.

Malinen, O., Savolainen, H., Engelbrecht, P., Xu, J., Nel, M., \& Tlale D. (2013). Exploring teacher self-efficacy for inclusive practices in three diverse countries. Teaching and Teacher Education, 33(July), 34-44. doi:10.1016/j.tate.2013.02.004.

Mittler, P. (2000). Working Towards Inclusive Education: Social Contexts. London, David Fulton.

Norwich, B. (2013). Addressing Tensions and Dilemmas in Inclusive Education: Living with Uncertainty. New York: Routledge.

OECD (2005). Teachers matter. Attracting, developing and retaining effective teachers. Paris: OECD. Retrieved from http://www.oecd.org/edu/school/attractingdevelopingandretainingeffectiveteachersfinalreportteachersmatter.htm.

OECD (2009). Creating Effective Teaching and Learning Environments: First Results from TALIS. Available at: www.oecd.org/edu/school/43023606.pdf.

OECD (2014a). TALIS 2013 results: An International Perspective on Teaching and Learning. Available at: http://dx.doi.org/10.1787/9789264196261-en.

OECD (2014b). TALIS 2013 technical report. Available at: www.oecd.org/edu/school/TALIS-technical-report-2013.pdf.

OECD (2015). Education at a Glance 2015. OECD Indicators. OECD Publishing. Retrieved from: http://dx.doi.org/10.1787/eag-2015-en.

Pace, E.M., \& Aiello, P. (2015). Facing complexity of inclusive classrooms through reflection on simplex principles. Athens: ATINER'S Conference Paper Series, No: EDU2015-1634, 1-14.

Putman, M.S. (2012). Investigating Teacher Efficacy: Comparing Preservice and Inservice Teachers with Different Levels of Experience. Action in Teacher Education, 34(1), 26-40. doi:10.1080/01626620.2012.642285.

Raudenbuch, S., Rowen, B., \& Cheong, Y. (1992). Contextual effects on the selfperceived efficacy of high school teachers. Sociology of Education 65(2), 150-167. doi: $10.2307 / 2112680$.

Rimer, B. \& Glanz, K. (2005). Theory at a Glance (2 ${ }^{\text {nd }}$ Ed). U.S.A.: National Institutes of Health U.S. Department of Health and Human Services. 
Rivoltella, P.C. (2012). Neurodidattica. Insegnare il cervello che apprende. Milano: Raffaello Cortina.

Rivoltella, P.C. (2014). La previsione. Neuroscienze, apprendimento e didattica. Brescia: La Scuola.

Rivoltella, P.C. (2015). Didattica Inclusiva con gli EAS. Brescia: La Scuola.

Ross, J., Cousins, J., \& Gadalla, T. (1996). Within-teacher predictors of teacher efficacy. Teaching and Teacher Education, 12, 385-400. doi:10.1016/0742051X(95)00046-M.

Rossi, P.G. \& Giaconi, C. (Eds.) (2016). Micro-progettazione: Pratiche a Confronto: PROPIT, EAS, Flipped Classroom. Milano: FrancoAngeli.

Round, P.N., Subban, P.K. \& Sharma, U. (2015). 'I don't have time to be this busy.' Exploring the concerns of secondary school teachers towards inclusive education. International Journal of Inclusive Education. doi:10.1080/13603116.2015.1079271.

Saloviita, T. (2015). Measuring pre-service teachers' attitudes towards inclusive education: Psychometric properties of the TAIS scale. Teaching and Teacher Education, 52 (2015), 66-72.

Savolainen, H., Engelbrecht, P., Nel, M., \& Malinen, O. (2012). Understanding teachers' attitudes and self-efficacy in inclusive education: Implications for preservice and in-service teacher education. European Journal of Special Needs Education, 27(1), 51-68. doi: 10.1080/08856257.2011.613603.

Semmel, M.I., Abernathy, T.V., Butera, G., \& Lesar, S. (1991). Teacher perceptions of the Regular Education Initiative. Exceptional Children, 58(1), 9-24.

Sharma U., \& Desai I. (2002). Measuring concerns about integrated education in India. Asia \& Pacific Journal on Disability, 5(1), 2-14.

Sharma, U., Forlin, C., \& Loreman, T. (2008). Impact of training on pre-service teachers' attitudes and concerns about inclusive education and sentiments about persons with disabilities. Disability \& Society, 23(7), 773-785.

Sharma, U. \& Jacobs, K. (2016). Predicting in-service educators' intentions to teach in inclusive classrooms in India and Australia. Teaching and Teacher Education, 55, 13-23.

Sharma, U., Loreman, T., \& Forlin, C. (2011). Measuring teacher efficacy to implement inclusive practices. Journal of Research in Special Educational Needs, 12(1), 12-21. doi: 10.1111/j.1471-3802.2011.01200.x.

Sharma, U., Moore, D., \& Sonawane, S. (2009). Attitudes and concerns of pre-service teachers regarding inclusion of students with disabilities into regular schools in Pune, India. Asia-Pacific Journal of Teacher Education, 37(3), 319-331.

Sharma, U., \& Nuttal, A. (2015). The impact of training on preservice teacher attitudes, concerns, and efficacy towards inclusion. Asia-Pacific Journal of Teacher Education. doi: 10.1080/1359866X.2015.1081672.

Sharma, U., Shaukat, S., \& Furlonger, B. (2014), Attitudes and Self-efficacy of preservice teachers towards inclusion in Pakistan. Journal of Research in Special Educational Needs, 15(2), 97-105. doi: 10.1111/1471-3802.12071.

Sharma, U., \& Sokal, L. (2015). The impact of a teacher education course on preservice teachers' beliefs about inclusion: an international comparison. Journal of 
Research in Special Educational Needs, 15, 276-284. http://dx.doi.org/10.1111/1471-3802.12043.

Shepherd, R., Sparks, P. \& Guthrie, C. A. (1995). The application of the Theory of Planned Behaviour to consumer food choice. E-European Advances in Consumer Research, 2, 360-365. Flemming Hansen, Provo, UT : Association for Consumer Research. Available at: http://acrwebsite.org/volumes/11624/volumes/e02/E-02.

Sibilio, M. (2014). La didattica semplessa. Napoli: Liguori

Sibilio, M., Aiello, P. \& Corona, F. (2013). Una didattica "semplessa" per i Disturbi Specifici dell'Apprendimento. In L. D'Alonzo, P. Aiello, F. Bocci, R. Caldin, F. Corona, P. Crispiani, F. Falcinelli, S. Maggiolini, R. Militerni, S. Visentin, M. Sibilio, DSA Elementi di didattica per $i$ bisogni educativi speciali, pp. 53-67, Milano, ETAS - RCS Libri.

Sideridis G., \& Chandler, J. (1995). Estimates of reliabilities for the teacher integration attitudes questionnaire. Perceptual \& Motor Skills, 80(3), 12-14.

Sliwka, A. (2010). From homogeneity to diversity in German education. In OECD, Educating Teachers for Diversity: Meeting the Challenge, pp. 205-216, OECD Publishing, Paris. doi: http://dx.doi.org/10.1787/9789264079731-12-en.

Stoiber, K. C., Gettinger, M., \& Goetz, D. (1998). Exploring factors influencing parents' and early childhood practitioners' beliefs about inclusion. Early Childhood Research Quarterly, 13, 107-124.

Theodorakis, Y, Bagiatis, K. \& Goudas, M. (1995). Attitude towards teaching individuals with disabilities: Application of the Theory of Planned Behaviour. Adapted Physical Activity Quarterly, 12, 151-160.

Tschannen-Moran, M. \& Woolfolk Hoy, A. (2001). Teacher efficacy: capturing an elusive construct. Teaching and Teacher Education, 17(7), 783-805. doi:10.1016/S0742-051X(01)00036-1.

Tschannen-Moran, M., Woolfolk Hoy, A. \& Hoy, W.K. (1998). Teacher efficacy: Its meaning and measure. Review of Educational Research, 68(2), 202-248.

UNESCO (1990). World Declaration on Education For All. Paris: UNESCO.

UNESCO (1994). Statement and framework for action on special needs education. adopted by the world conference on special needs education: access and quality. Paris: UNESCO.

UNESCO (2000). Education for All: Meeting Our Collective Commitments. Notes on the Dakar framework for Action. Paris: UNSECO.

Weisel, A., \& Dror, O. (2006). School climate, sense of efficacy and Israeli teachers' attitudes toward inclusion of students with special needs. Education, Citizenship and Social Justice, 1(2), 157-174.

WHO (2011). World Health Report on Disability. World Health Organisation. Retrieved from: http://www.who.int/disabilities/world report/2011/en/.

Wilczenski, F. L. (1992). Reevaluating the factor structure of the attitudes toward mainstreaming scale. Educational \& Psychological Measurement, 52, 499-504. 


\section{Appendix 1}

Table 1. Scales to Measure Teachers' Willingness to Implement Inclusive Practices

\begin{tabular}{|c|c|c|c|c|}
\hline Year & Authors & Scale & $\begin{array}{l}\text { N. of } \\
\text { Items }\end{array}$ & Reliability \\
\hline 1979 & Larivee \& Cook & $\begin{array}{lrl}\text { Opinions } & \text { Relative } & \text { to } \\
\text { Mainstreaming (ORM) } & \end{array}$ & 30 & $\alpha=.89$ \\
\hline 1980 & Berryman \& Neal & $\begin{array}{lr}\text { Attitudes } & \text { Towards } \\
\text { Mainstreaming } & \text { Scale } \\
\text { (ATMS) } & \\
\end{array}$ & 18 & $\alpha=.89$ \\
\hline 1982 & $\begin{array}{l}\text { Ashton, Olejnik, Crocker } \\
\& \text { McAuliffe }\end{array}$ & Ashton Vignettes & 50 & $\mathrm{NA}^{*}$ \\
\hline 1991 & $\begin{array}{l}\text { Semmel, Abernathy, } \\
\text { Butera \& Lesar }\end{array}$ & $\begin{array}{l}\text { Regular Education Initiative } \\
\text { Teacher Survey (REITS) }\end{array}$ & 27 & $\alpha=.82$ \\
\hline 1992 & Wilczenski & $\begin{array}{l}\text { Attitudes Towards Inclusive } \\
\text { Education Scale (ATIES) }\end{array}$ & 16 & $\alpha=.92$ \\
\hline 1995 & Antonak \& Larrivee & $\begin{array}{l}\text { Opinions Relative to } \\
\text { Integration of Students with } \\
\text { Disabilities (ORI) [Revision of } \\
\text { the ORM (Larivee \& Cook, } \\
\text { 1979)] }\end{array}$ & 30 & $\alpha=.83$ \\
\hline 1995 & Bender, Vail \& Scott & $\begin{array}{ll}\text { Mainstreaming } & \text { Attitudes } \\
\text { Survey (MAS) } & \end{array}$ & NA & NA \\
\hline 1995 & Sideridis and Chandler & $\begin{array}{l}\text { Teacher Integration Attitudes } \\
\text { Questionnaire (TIAQ) }\end{array}$ & 12 & $\alpha=.92$ \\
\hline 1997 & Bandura & $\begin{array}{l}\text { Bandura's Teacher Self- } \\
\text { Efficacy Scale }\end{array}$ & 30 & NA \\
\hline 1998 & $\begin{array}{l}\text { Stoiber, Gettinger \& } \\
\text { Goez }\end{array}$ & $\begin{array}{l}\text { My Thinking About Inclusion } \\
\text { questionnaire - Short Form } \\
\text { (MTAI-SF) }\end{array}$ & 12 & $\alpha=.80$ \\
\hline 1998 & $\begin{array}{l}\text { Stoiber, Gettinger \& } \\
\text { Goez }\end{array}$ & $\begin{array}{l}\text { My Thinking About Inclusion } \\
\text { questionnaire (MTAI) }\end{array}$ & 28 & $\alpha=.91$ \\
\hline 1998 & Cochran & $\begin{array}{l}\text { Scale of Teachers' Attitudes } \\
\text { Toward } \\
\text { Classrooms (STATIC) }\end{array}$ & 20 & $\alpha=.89$ \\
\hline 2001 & $\begin{array}{l}\text { Tschannen-Moran } \\
\text { Woolfolk Hoy }\end{array}$ & $\begin{array}{l}\text { Teacher Self Efficacy Scale } \\
{[\text { Translated into Italian and }} \\
\text { validated for Italian contexts } \\
\text { by Biasi et al, 2014)] }\end{array}$ & $12-24$ & $\alpha=.90$ \\
\hline 2002 & Sharma \& Desai & $\begin{array}{l}\text { Concerns about Inclusive } \\
\text { Education Scale (CIES) } \\
\text { [Translated into Italian and is } \\
\text { currently being validated by } \\
\text { the authors] }\end{array}$ & 21 & $\alpha=.86$ \\
\hline
\end{tabular}




\begin{tabular}{|c|c|c|c|c|}
\hline Year & Authors & Scale & $\begin{array}{l}\text { N. of } \\
\text { ltems }\end{array}$ & Reliability \\
\hline 2004 & Bailey & $\begin{array}{lll}\text { Teachers' } & \text { Attitude } & \text { toward } \\
\text { Inclusion Scale } & \text { (TATIS) } \\
\text { (used by Sharma \& Nutal } \\
\text { with teachers) }\end{array}$ & 24 & $\alpha=.91$ \\
\hline 2007 & $\begin{array}{lll}\text { Alvarez } & \text { Mchatton } \quad \& \\
\text { McCray } & & \\
\end{array}$ & $\begin{array}{l}\text { Inclination Toward Inclusion } \\
\text { (ATI) }\end{array}$ & $22-28$ & $\alpha=.91$ \\
\hline 2007 & $\begin{array}{l}\text { Loreman, Earle, Sharma } \\
\text { \& Forlin }\end{array}$ & $\begin{array}{l}\text { Sentiments, Attitudes, } \\
\text { Concerns regarding Inclusive } \\
\text { Education (SACIE) }\end{array}$ & 19 & missing \\
\hline 2007 & Kuyini \& Desai & $\begin{array}{l}\text { Knowledge of Inclusive } \\
\text { Education Scale (KIES) }\end{array}$ & 16 & $\alpha=.88$ \\
\hline 2008 & Mahat & $\begin{array}{l}\text { Multidimensional } \text { Attitudes } \\
\text { toward Inclusive } \\
\text { Scale (MATIES) }\end{array}$ & 18 & $\alpha=.91$ \\
\hline 2010 & Cullen, Gregory \& Noto & $\begin{array}{l}\text { Teacher Attitude Toward } \\
\text { Inclusion Scale }\end{array}$ & 14 & $\alpha=.82$ \\
\hline 2011 & $\begin{array}{l}\text { Forlin, Earle, Loreman \& } \\
\text { Sharma }\end{array}$ & $\begin{array}{l}\text { Sentiments, Attitudes, } \\
\text { Concerns regarding Inclusive } \\
\text { Education - Revised (SACIE- } \\
\text { R) [Revision of the SACIE } \\
\text { scale (Loreman et al., 2007)] } \\
\text { [Translated into Italian and } \\
\text { validated for Italian contexts } \\
\text { (Aiello et al., 2016)] }\end{array}$ & 15 & $\alpha=.74$ \\
\hline 2011 & $\begin{array}{l}\text { Sharma, Loreman \& } \\
\text { Forlin }\end{array}$ & $\begin{array}{l}\text { Teacher Efficacy for } \\
\text { Inclusive Practice (TEIP) } \\
\text { scale } \\
\text { [Translated into Italian and } \\
\text { validated for Italian contexts } \\
\text { (Aiello et al., 2016)] }\end{array}$ & 18 & $\alpha=.89$ \\
\hline 2013 & $\begin{array}{l}\text { Ahmmed, Sharma \& } \\
\text { Deppeler }\end{array}$ & $\begin{array}{l}\text { Perceived School Support for } \\
\text { Inclusive Education (PSSIE) }\end{array}$ & 8 & NA \\
\hline 2015 & Saloviita & $\begin{array}{l}\text { Teachers' Attitudes towards } \\
\text { Inclusive Education (TAIS) }\end{array}$ & 10 & $\alpha=.89$ \\
\hline 2016 & Sharma \& Jacobs & $\begin{array}{l}\text { Attitudes towards Inclusion } \\
\text { Scale (AIS) } \\
\text { [Translated into Italian and is } \\
\text { currently being validated by } \\
\text { the authors] }\end{array}$ & 10 & missing \\
\hline 2016 & Sharma \& Jacobs & $\begin{array}{l}\text { Intention to Teach in } \\
\text { Inclusive Classrooms (ITICS) } \\
\text { [Translated into Italian and is } \\
\text { currently being validated by } \\
\text { the authors] }\end{array}$ & 7 & missing \\
\hline
\end{tabular}

*Note: NA - access was limited to abstract or parts of document only; Missing - not reported in the article 